\section{West African Economic and Monetary Union (UEMOA)}

Founded in 1994, the UEMOA (Union Economique et Monétaire Ouest Africaine) aims to reinforce the competitiveness of the economic and financial activities of member states in the context of an open and rival market and a rationalized and harmonized juridical environment; to ensure the convergence of the macro-economic performances and policies of member states; to create a common market among member states; to institute a co-ordination for the national sector-based policies; and to harmonize the legislation, especially the fiscal system, of the member states.

Members. Benin, Burkina Faso, Côte d'Ivoire, Guinea-Bissau, Mali, Niger, Senegal, Togo.

Headquarters: 01 B.P. 543, Ouagadougou 01, Burkina Faso. Website: http://www.uemoa.int

President: Soumaïla Cisse (Mali).

\section{Agency for the Prohibition of Nuclear Weapons in Latin America and the Caribbean (OPANAL)}

The Agency (Organismo para la Proscripción de las Armas Nucleares en la América Latina y el Caribe) was established following the Cuban missile crisis to guarantee implementation of the world's first Nuclear-Weapon-Free-Zone (NWFZ) in the region. Created by the Treaty of Tlatelolco (1967), OPANAL is an inter-governmental agency responsible for ensuring that the requirements of the Treaty are enforced. OPANAL has played a major role in establishing other NWFZs throughout the world.

Organization. The Agency consists of three main bodies: the General Conference which meets for biennial sessions and special sessions when deemed necessary; the Council of OPANAL consisting of five member states which meet every two months plus special meetings when necessary; and the Secretariat General.

Members of the Treaty. Antigua and Barbuda, Argentina, Bahamas, Barbados, Belize, Bolivia, Brazil, Chile, Colombia, Costa Rica, Cuba, Dominica, Dominican Republic, Ecuador, El Salvador, Grenada, Guatemala, Guyana, Haiti, Honduras, Jamaica, Mexico, Nicaragua, Panama, Paraguay, Peru, St Kitts and Nevis, St Lucia, St Vincent and the Grenadines, Suriname, Trinidad and Tobago, Uruguay, Venezuela.

Headquarters: Schiller No. 326, 5th Floor, Col. Chapultepec Morales, México, D. F. 11570, Mexico.

Website: http://www.opanal.org

e-mail: info@opanal.org

Secretary-General: Edmundo Vargas Carreño (Chile).

\section{Andean Community}

On 26 May 1969 an agreement was signed by Bolivia, Chile, Colombia, Ecuador and Peru establishing the Cartagena Agreement (also referred to as the Andean Pact or the Andean Group). Chile withdrew from the Group in 1976. Venezuela, which was actively involved, did not sign the agreement until 1973. In 1997 Peru announced its withdrawal for five years.

The Andean Free Trade Area came into effect on 1 Feb. 1993 as the first step towards the creation of a common market. Bolivia, Colombia, Ecuador, Peru and Venezuela have fully liberalized their trade. A Common External Tariff for imports from third countries has been in effect since 1 Feb. 1995.

In March 1996 at the Group's 8th summit in Trujillo in Peru, member countries (Bolivia, Colombia, Ecuador, Peru, Venezuela) set up the Andean Community, to promote greater economic, commercial and political integration between member countries under a new Andean Integration System (SAI).

The member countries and bodies of the Andean Integration System are working to establish an Andean Common Market and to implement a Common Foreign Policy, a social agenda, a Community policy on border integration, and policies for achieving joint macroeconomic targets.

Organization. The Andean Presidential Council, composed of the presidents of the member states, is the highest-level body of the Andean Integration System (SAI). The Commission and the Andean Council of Foreign Ministers are legislative bodies. The General Secretariat is the executive body and the Andean Parliament is the deliberative body of the SAI. The Court of Justice, which began operating in 1984, resolves disputes between members and interprets legislation. The SAI has other institutions: Andean Development Corporation (CAF), Latin American Reserve Fund (FLAR), Simon Bolivar Andean University, Andean Business Advisory Council, Andean Labour Advisory Council and various Social Agreements.

Further to the treaty signed by 12 South American countries in Dec. 2004, the Andean Community will gradually be integrated into the new South American Community of Nations.

Official language: Spanish.

Headquarters: Avda Paseo de la República 3895, San Isidro, Lima 17, Peru.

Website: http://www.comunidadandina.org

e-mail: contacto@comunidadandina.org

Secretary-General: Allan Wagner Tizón (Peru).

\section{Association of Caribbean States (ACS)}

The Convention establishing the ACS was signed on 24 July 1994 in Cartagena de Indias, Colombia, with the aim of promoting consultation, co-operation and concerted action among all the countries of the Caribbean, comprising 25 full member states and three associate members. A total of eight other non-independent Caribbean countries are eligible for associate membership.

Members. Antigua and Barbuda, Bahamas, Barbados, Belize, Colombia, Costa Rica, Cuba, Dominica, Dominican Republic, El Salvador, Grenada, Guatemala, Guyana, Haiti, Honduras, Jamaica, Mexico, Nicaragua, Panama, St Kitts and Nevis, St Lucia, St Vincent and the Grenadines, Suriname, Trinidad and Tobago, Venezuela.

Associate members. Aruba, France (on behalf of French Guiana, Guadeloupe and Martinique) and the Netherlands Antilles.

The CARICOM Secretariat, the Latin American Economic System (SELA), the Central American Integration System (SICA) and the Permanent Secretariat of the General Agreement on Central American Economic Integration (SIECA) were declared Founding Observers of the ACS in 1996. The United Nations Economic Commission for Latin America and the Caribbean (ECLAC) and the Caribbean Tourism Organization (CTO) were admitted as Founding Observers in 2000 and 2001 respectively. 